\title{
Defining scales of the land use effect to map the urban heat island in a mid-size European city: Rennes (France)
}

X. Foissard ${ }^{\mathrm{a}}$, V. Dubreuil ${ }^{\mathrm{a}}$, H. Quénol ${ }^{\mathrm{a}}$

${ }^{\text {a }}$ Laboratory LETG, CNRS, University of Rennes 2, Place du Recteur Henri Le Moal, 35000 Rennes, France. 


\begin{abstract}
The Urban Heat Island (UHI) is a climatic phenomenon linked to urbanization. In the context of climate change, municipalities have to adapt the city to increase in heat waves by managing the UHI. This study aims to map the UHI of a mid-size city (Rennes, France) and to define the relevant land use factors. The UHI was measured by 22 weather stations in different contexts: urban, suburban and periurban. After investigating the UHI weather conditions, we used a multi-criteria method by linear regression to build a model of the UHI. It explained $82 \%$ of UHI spatial variability for an average year. This method was automated to map the UHI for several periods (annual, seasonal, and daily). The influence of the land use on the UHI fluctuated with weather conditions. We tested different land use factors for several scales (100m to $900 \mathrm{~m})$. The results show the preponderance of low vegetation fraction and built-up fraction variables to explain the UHI with a buffer radius of $200 \mathrm{~m}$ and $900 \mathrm{~m}$ respectively. We conclude that these variables are relevant to define indexes for town planners.
\end{abstract}

Keywords: Urban Heat Island (UHI), weather station, air temperature, regression model, spatial analysis, local scales. 


\section{Introduction}

The world population has reached approximately 7 billion inhabitants. In recent decades, populations have been shifting from rural to urban areas. In 1950, 30\% of the population lived in cities, while nowadays this proportion has risen to $54 \%$ (United Nations, 2013). This demographic trend of world urbanization causes local climate change due to building development, and the sprawl of impervious surfaces. One of these city climate phenomena is the urban heat island (UHI). It is defined as the difference in nocturnal air temperatures between the city center and surrounding rural areas (Oke, 1987, 1982). Most studies focus on the UHI in large cities, while the UHI of mid-sized cities (comprising 50,000 to 500,000 inhabitants) remains insufficiently evaluated and mapped (Amorim et al., 2009). Our study case is located in Rennes (France) with a weather station network to measure this phenomenon (Dubreuil et al., 2011; Quénol et al., 2010).

Also, during heat waves, the UHI is a factor that leads to heat stress or, in extreme situations, overmortality (Besancenot, 2002; Gabriel and Endlicher, 2011; Rousseau, 2005; Stéphan et al., 2005). In the context of climate change, the fifth report of the Intergovernmental Panel on Climate Change (IPCC) showed an increase in the number of heat waves and tropical nights since 1950 (Hartmann et al., 2013). A study carried out in Paris shown that the temperature rose $+0.5^{\circ} \mathrm{C}$ due to air-conditioning during the heat wave of 2003 (de Munck et al., 2012; Tremeac et al., 2012). These elements highlight the number of days during which the UHI becomes sensitive. Consequently, French municipalities have to plan strategies to reduce the effect of climate change in cities, especially with regard to the UHI. Planners therefore seek decision-making tools to write policy documentation. The results emphasize the need to build actions and thus to reduce energy consumption in the city. To develop effective climate adaptation strategies, the UHI phenomenon needs to be understood and mapped.

In France, previous research in the cities of Paris, Marseilles, and Toulouse has dealt with numerical modeling of the UHI according to a physical approach. These studies used the TEB (Town Energy Balance) model developed by Météo-France (CNRM) (Masson, 2000; Masson et al., 2008, 2002; Pigeon et al., 2007). The maximum UHI intensity measured in Paris reached $+8^{\circ} \mathrm{C}$ during the heatwave of summer 2003 (de Munck et al., 2012). Our study deals with the UHI in Rennes (France) to observe this phenomenon with a network of weather stations and to map temperature associated with the UHI throughout the city using a geostatistical approach. We use two nested scales (from the urban area to the neighborhood level) to analyze spatial variability according to land use.

Mapping the UHI requires a model to be run in order to process discrete meteorological observation into a continuous spatial range. This issue in geography is common, especially in climatology. The statistical model is based on in-situ measurements to characterize the UHI phenomenon. We distinguish two main approaches of interpolation: a geostatistical method and a multi-criteria method. The first method relates to a spatial autocorrelation that is the maximum likeness of a point with its neighbors. The second method involves a stochastic approach and specifies the variability and the error (Li and Heap, 2014; Szymanowski and Kryza, 2011). In this study, we use the multi-criteria

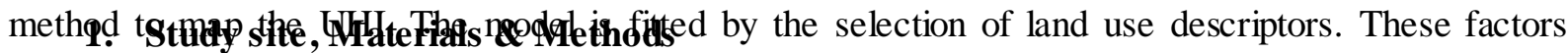
providel thatyedf(2) form.

Rennes $\left(48^{\circ} 7^{\prime} \mathrm{N}\right.$ and $\left.1^{\circ} 40^{\prime} \mathrm{W}\right)$ is in the west of France, more precisely in eastern Brittany and the distance to the sea is $70 \mathrm{~km}$. It is the $11^{\text {th }}$ largest city in France with 210,000 inhabitants. The urban area comprises 43 municipalities with 420,000 inhabitants in $700 \mathrm{~km}^{2}$. It is located in the north of a 
small basin with low elevation (between $20 \mathrm{~m}$ to $100 \mathrm{~m}$ ). A forest covers the northern part of the area and extends over a surface area of 3,000ha.

The region of Rennes is under the influence of a temperate oceanic climate, more specifically $\mathrm{Cfb}$ according to the Köppen-Geiger classification (Eveno et al., 2016). The annual mean temperature is $12.1^{\circ} \mathrm{C}$ with an average daily maximum temperature in July of $24.5^{\circ} \mathrm{C}$, and the number of "summer days" per year is nearly 40 days per year. These "summer days" are defined by the number of days where $\mathrm{T}_{\operatorname{ma}} \geq 25^{\circ} \mathrm{C}$, according to the ETCCDI indices (Karl et al., 1999; Peterson et al., 2001; Zhang et al., 2005). Furthermore, the number of warm days where $T_{\max } \geq 30^{\circ} \mathrm{C}$, is 8 days per year.

Precipitation is moderate and constant throughout the year and the mean rainfall is about $700 \mathrm{~mm}$. The month with the greatest amount of rainfall is October $(77.3 \mathrm{~mm})$ and the least rainy month is August $(37.6 \mathrm{~mm})$. The oceanic climate causes high variability in the weather and a priori unfavorable situation for a strong UHI development. Therefore, the number of days with daily precipitation under $1 \mathrm{~mm}$ is equivalent to 255.6 days/year. Also, daily insolation is above $75 \%$ for only 63.9 days/year. This variability of weather types determines the presence of the UHI (Landsberg, 1981; Oke, 1982). The weather conditions which lead to the presence of the UHI, with a combination of a clear sky and low wind (less than $3 \mathrm{~m} . \mathrm{s}^{-1}$ ), are present about $10 \%$ of the time (Foissard et al., 2012).

\subsection{The city scale network}

The UHI phenomenon requires a measurement network adapted to the city scale, i.e. a local scale, to be set up. In the urban area, the climate includes several nested scales whose dimensions fluctuated according to the close environment. The aim of sensor measurements was to be representative of temperature in the neighborhood, hence it was important to avoid micro-scale effects (for instance due to roads, trees, walls) (Oke, 2006).

As a result of the multidisciplinary research program ECORURB (rural to urban ecology), this first program led to the installation of the first network of weather stations in 2004 (Dubreuil et al., 2011). The objective of this protocol was to observe climate factors in the long-term between the rural and the urban environment. The weather stations were Weather Monitor II and Vantage Pro 2 devices from DAVIS Instruments. The precision provided by the manufacturer was $+/-0.5^{\circ} \mathrm{C}$. All weather stations were installed in the same place and showed that the average temperature difference was between $+0.17^{\circ} \mathrm{C}$ and $-0.09^{\circ} \mathrm{C}$. This result meant that more than $95 \%$ of the observations are accurate within $+/-$ $0.5^{\circ} \mathrm{C}$. These measurements fulfilled the UHI observations at local scale. 


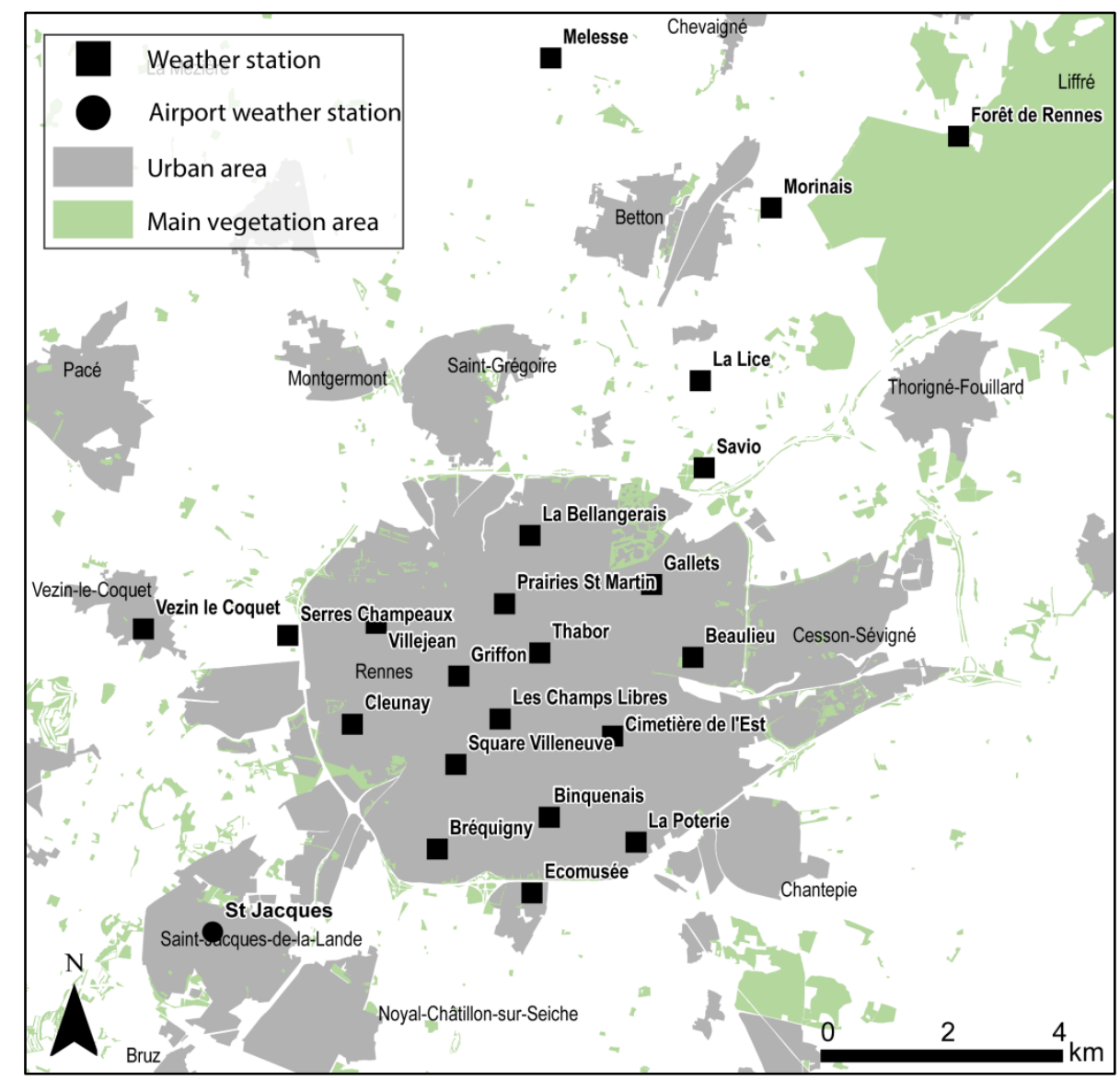

Figure 1, Weather stations in the metropolitan area of Rennes

The setting up of weather stations has to allow for spatial variability and has to take into account the characteristics of the city (Figure 1). In this study, we used 22 weather stations (including the $S t$ Jacques airport weather station) and we classified them according to three groups of urban areas in Rennes: center, suburban, and periurban (Figure 2). We defined the urban area classification according to land use information (building and vegetation fractions).

- The sites identified as "center" included significant impervious surface areas with a high coverage of intensively built-up areas, usually higher than $40 \%$. This group included the old city center with high patrimonial value, comprising medieval-style buildings with narrow streets. The center of Rennes is also composed of areas of more contemporary blocks of flats, with a fraction of buildings the same as those found in the old center. The average building height is $15 \mathrm{~m}$, and the total surface area of the center is $2 \mathrm{~km}^{2}$. The Griffon weather station is located in the old center while Les Champs Libres is in the recent part of the center.

- The "suburban" group included the other urban areas of Rennes. This group was located in the city of Rennes and the urban part of surrounding towns. The morphology of this area is miscellaneous with many kinds of buildings (towers, low-rise buildings, townhouses, and detached houses). The vegetation cover ranges from $15 \%$ to $50 \%$, while the building cover is more homogenous with $10 \%$ to $30 \%$.

- The countryside of Rennes made up the last group named "peri-urban". This area is composed of fields, some farms and individual houses with a low share of impervious surfaces (less than $15 \%$ ) except for the sites near the urban area (like Ecomusée, Champeaux, and Saint-Jacques). In contrast, the vegetation cover represents at least $50 \%$.

In order to observe the UHI variability, we selected two weather stations to define the difference between the rural and the urban areas. The rural reference station was Melesse in the north of Rennes 
(above $11 \mathrm{~km}$ ). This site is characterized by agricultural land with hedges and a few buildings (the built-up area fraction is under $1 \%, c f$. Figure 2). We considered that the local climate of Melesse was not influenced by urbanization rather than the synoptic reference station which stands only $6 \mathrm{~km}$ from the center to the city. Conversely, the urban weather station reference was in the center of the city of Rennes to measure the maximum UHI intensity. This station, named Griffon, was selected due to the densely built-up areas (40\%) and high impervious surface areas (51\%). The comparison of these sites showed the greatest difference in temperature according to UHI phenomenon. The last column in Figure 2 provides information about the typical LCZ of each station.

To compare the urban morphology according the UHI, Stewart and Oke developed the Local Climate Zone (LCZ) classification (Stewart and Oke, 2012). They built a framework for the type of neighborhood in a city. This classification aims to compare worldwide landscapes in cities with LCZs. We identified 10 LCZs in the metropolitan area of Rennes: 5 types of built-up LCZs (LCZ 2-5-6-8-9) with 5 kinds of surfaces (LCZ A-B-D-E-G). The center consists of LCZ 2, while the suburban part of the city was heterogeneous with the other LCZs. One should remember that LCZ are usually define in a $200 \mathrm{~m}$ context, but we present here a more extensive description (a $500 \mathrm{~m}$ radius) so that the threshold proposed by Stewart and Oke does not match exactly.

\subsection{The selection of the 89 relevant days with UHI in 2011}

The weather types influence the temporal variability of the UHI, thus the aim was to define the weather parameters measured when the UHI is present. The analysis was conducted for a one-year period (2011) which was complete and representative in accordance with the seasonal variability of the UHI. Here, the UHI was estimated by the difference in the minimum temperature $\left(\Delta \mathrm{T}_{\min }\right)$ between the urban reference (Griffon) and the rural reference (Melesse) during the favorable atmospheric conditions. The main weather factors are wind and cloud cover (Kim and Baik, 2002; Morris and Simmonds, 2001). These data were provided by the airport weather station (Météo-France services). This synoptic scale information was used to determine atmospheric conditions when the minimum temperature $\left(\mathrm{T}_{\min }\right)$ was recorded.

The UHI is present in the center throughout the year. The average difference in temperature between the center (Griffon) and the rural area (Melesse) was $+1.3^{\circ} \mathrm{C}$ in 2011 (Figure 3). However, the UHI is only a nocturnal effect with an average difference of $+2.6^{\circ} \mathrm{C}$ in the minimum temperature $\left(\Delta \mathrm{T}_{\min }\right)$, while the average difference in maximum temperature $\left(\Delta \mathrm{T}_{\max }\right)$ was $+0.0^{\circ} \mathrm{C}$ in 2011 . Figure 3 shows the temporal variability in the difference in temperature for the four three-months seasons (MAM, JJA, SON and DJF) and the time of the day in 2011. The highest average difference in temperature during the year was in spring $\left(+1.6^{\circ} \mathrm{C}\right)$ and in summer $\left(+1.3^{\circ} \mathrm{C}\right)$. Moreover, the period of day with the highest difference in temperature between the center and the rural area $\left(>+3^{\circ} \mathrm{C}\right)$ was between $8 \mathrm{pm}$ and 6 am (UTC). 


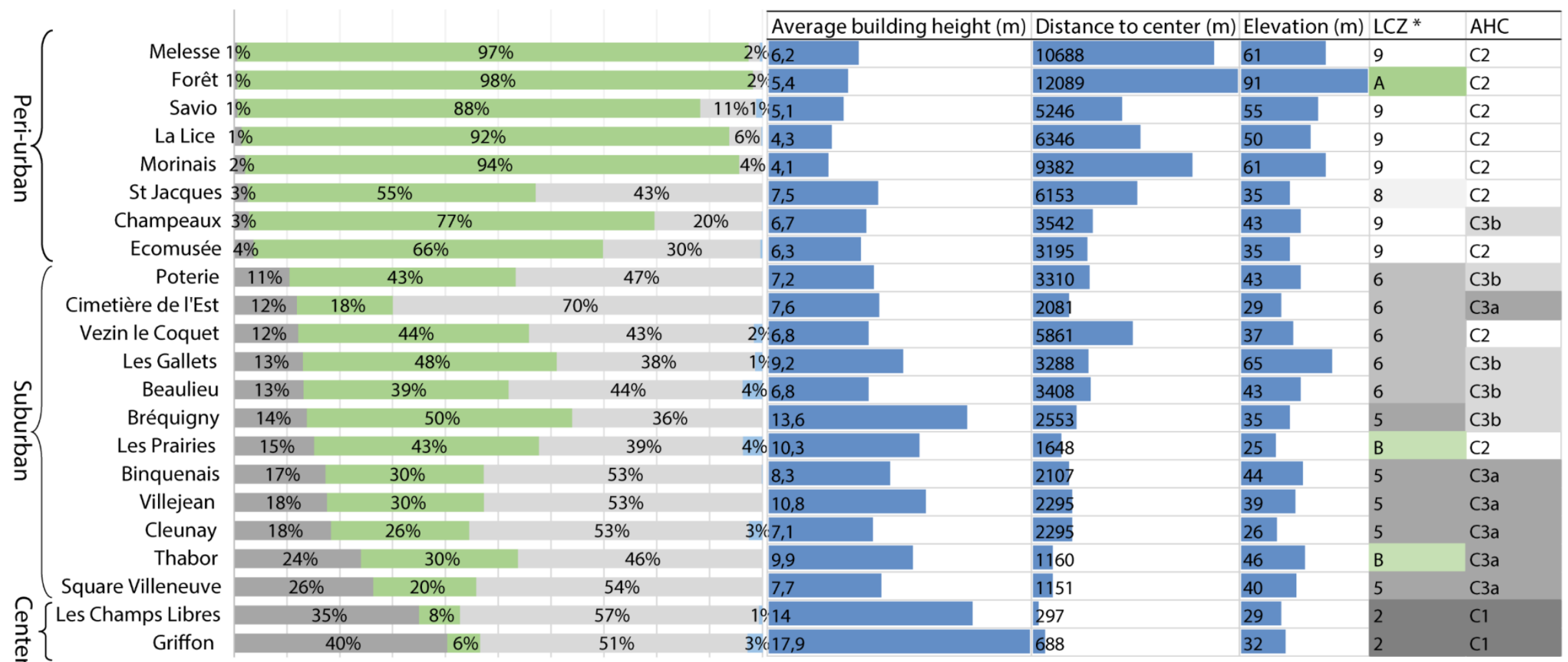

$\begin{array}{lllllllllll}0 \% & 10 \% & 20 \% & 30 \% & 40 \% & 50 \% & 60 \% & 70 \% & 80 \% & 90 \% & 100 \%\end{array}$

Building $\square$ Vegetation $\square$ Impervious surface $\backsim$ Water

Figure 2, Land use and surface geometrics of the close environment of weather stations within a buffer zone of 500m. (LCZ *) indicative basis for weather stations in a 200 m context according to methodology described by Stewart and Oke. 
Conversely the relative coolest period in the center was during the daytime between 9 am and 12 noon (UTC) due to the shadow effect inside the street canyon also known as a "urban cool is land". This can also be explained by the sensitive heat transfer to buildings and turbulences in the canopy boundary layer, both phenomena highlighted in different studies (Chow and Roth, 2006; Erell and Williamson, 2007; Fenner et al., 2014; Hidalgo et al., 2010; Kazimierz and Fortuniak, 1999; Middel et al., 2014; Oke and Maxwell, 1975; Pacifici et al., 2019; Suomi and Käyhkö, 2012).

As the UHI is linked to the variability of weather types, we defined weather conditions suitable to local climate phenomenon. The aim was to select the days with the UHI to observe the land use effect and to minimize the synoptic conditions effect. We set two meteorological parameters to select these days: cloud cover and wind speed. A two-step method was used to determine the days when the UHI was present. The first step was to ascertain when the difference in minimum temperature was significant. The threshold was $\Delta \mathrm{T}_{\min }=3^{\circ} \mathrm{C}$, based on which 137 days were selected in 2011 (Cantat, 2004; Kazimierz and Fortuniak, 1999). The second step was to choose the days with low cloud cover and low wind when $\Delta \operatorname{Tn}$ was measured. The definition of a "low cloud cover" was qualified as "clear" (no clouds), "few" (1/8 to $2 / 8)$ and "scattered" (3/8 to 4/8) following the METAR classification (Meteorological Aerodrome Report). This second criterion led to the selection of 89 days with the UHI, of which $70 \%$ were recorded between 5 am and 7 am UTC. This result was consistent with the description of UHI variability at nighttime (Oke, 1987). From these criteria, all the nights had low wind measured $(<5 \mathrm{~m} / \mathrm{s})$ at the $\mathrm{T}_{\min }$ time. Therefore $24 \%$ of nights in 2011 corresponded to the atmospheric situations for the UHI. For these conditions, the UHI reached $\Delta \mathrm{T}_{\min }=4.8^{\circ} \mathrm{C}$.

In accordance with the seasons, the UHI was more frequently present during the spring and summer months (respectively for 30 days and 28 days) than the fall and winter months (for 21 days and 10 days). This studied year of 2011 was specific with numerous sunny days in April and May (+43\% of sunshine duration with only 4 rain days per month). Conversely, the summer months were humid (25 rain days), but the summer extended in September and October with frequent clear sky days observed (55 days).

The synoptic conditions were summarized in the Table 1 when the UHI appeared. The wind speed average is nearly $1.1 \mathrm{~m} . \mathrm{s}^{-1}$ along the year with a prevailing direction from West. The cloud cover was mostly "Clear" and "Few" for all seasons except in winter with $40 \%$ of "Scattered" situation. The average of maximum temperature observed in these selected days was $21.0^{\circ} \mathrm{C}$ in 2011 , that was $+3.3^{\circ} \mathrm{C}$ more than the entire year. The highest difference of maximum temperature was respectively in fall $\left(+3.6^{\circ} \mathrm{C}\right)$, in spring $\left(+2.2^{\circ} \mathrm{C}\right)$, in summer $\left(+1.7^{\circ} \mathrm{C}\right)$ and in winter $\left(-0.5^{\circ} \mathrm{C}\right)$.

Table 1, the synoptic weather conditions observed when the UHI was present in 2011.

\begin{tabular}{|c|c|c|c|c|c|c|c|c|}
\hline \multirow{2}{*}{$\begin{array}{l}\text { Period } \\
\text { (number } \\
\text { of days) }\end{array}$} & \multirow{2}{*}{$\begin{array}{l}\Delta \mathrm{T}_{\min } \\
\left({ }^{\circ} \mathrm{C}\right)\end{array}$} & \multirow{2}{*}{$\begin{array}{l}\text { Wind speed } \\
\text { average } \\
(\mathrm{m} / \mathrm{s})\end{array}$} & \multirow{2}{*}{$\begin{array}{c}\text { Prevailing } \\
\text { wind direction }\end{array}$} & \multicolumn{2}{|c|}{ Cloud cover distribution } & \multirow{2}{*}{$\begin{array}{l}\mathrm{T}_{\min } \\
\left({ }^{\circ} \mathrm{C}\right)\end{array}$} & \multirow{2}{*}{$\begin{array}{l}\mathrm{T}_{\max } \\
\left({ }^{\circ} \mathrm{C}\right)\end{array}$} & \multirow{2}{*}{$\begin{array}{l}\mathrm{T}_{\text {avg }} \\
\left({ }^{\circ} \mathrm{C}\right)\end{array}$} \\
\hline & & & & Clear/Few & Scattered & & & \\
\hline $\begin{array}{c}\text { UHI in } \\
2011 \text { (89) }\end{array}$ & 4.8 & 1.1 & W & $92 \%$ & $8 \%$ & 5.4 & 21.0 & 13.3 \\
\hline $\begin{array}{c}\text { Winter } \\
(10)\end{array}$ & 4.0 & 1.3 & $S$ & $60 \%$ & $40 \%$ & 0.0 & 10.1 & 5.0 \\
\hline $\begin{array}{l}\text { Spring } \\
(30)\end{array}$ & 4.7 & 1.1 & W & $90 \%$ & $10 \%$ & 4.2 & 20.8 & 12.5 \\
\hline $\begin{array}{l}\text { Summer } \\
\text { (28) }\end{array}$ & 4.9 & 1,1 & $\mathrm{~W}$ & $100 \%$ & $0 \%$ & 7.9 & 24.3 & 16.1 \\
\hline $\begin{array}{l}\text { Fall } \\
(21)\end{array}$ & 5.3 & 1,0 & $\mathrm{E}$ & $100 \%$ & $0 \%$ & 6.5 & 22.4 & 14.5 \\
\hline
\end{tabular}




\subsection{Multi-criteria method for spatial modeling of UHI}

In this study, we chose an empirical method for modeling the UHI. This inductive approach consists in building a statistical model from data collected in situ. Two types of interpolation exist to spatialize discrete point data: a geostatistical method and a multi-criteria method. The second method includes a stochastic aspect provided by errors associated with the estimations, unlike the deterministic approach (Li and Heap, 2014). In the context of climatology applied to local scale, the multi-criteria method has been successfully used for spatialization (Alcoforado et al., 2009; Bottyan and Unger, 2003; Dubreuil et al., 2002; Szymanowski and Kryza, 2011b, 2009). This method requires an appropriate number of

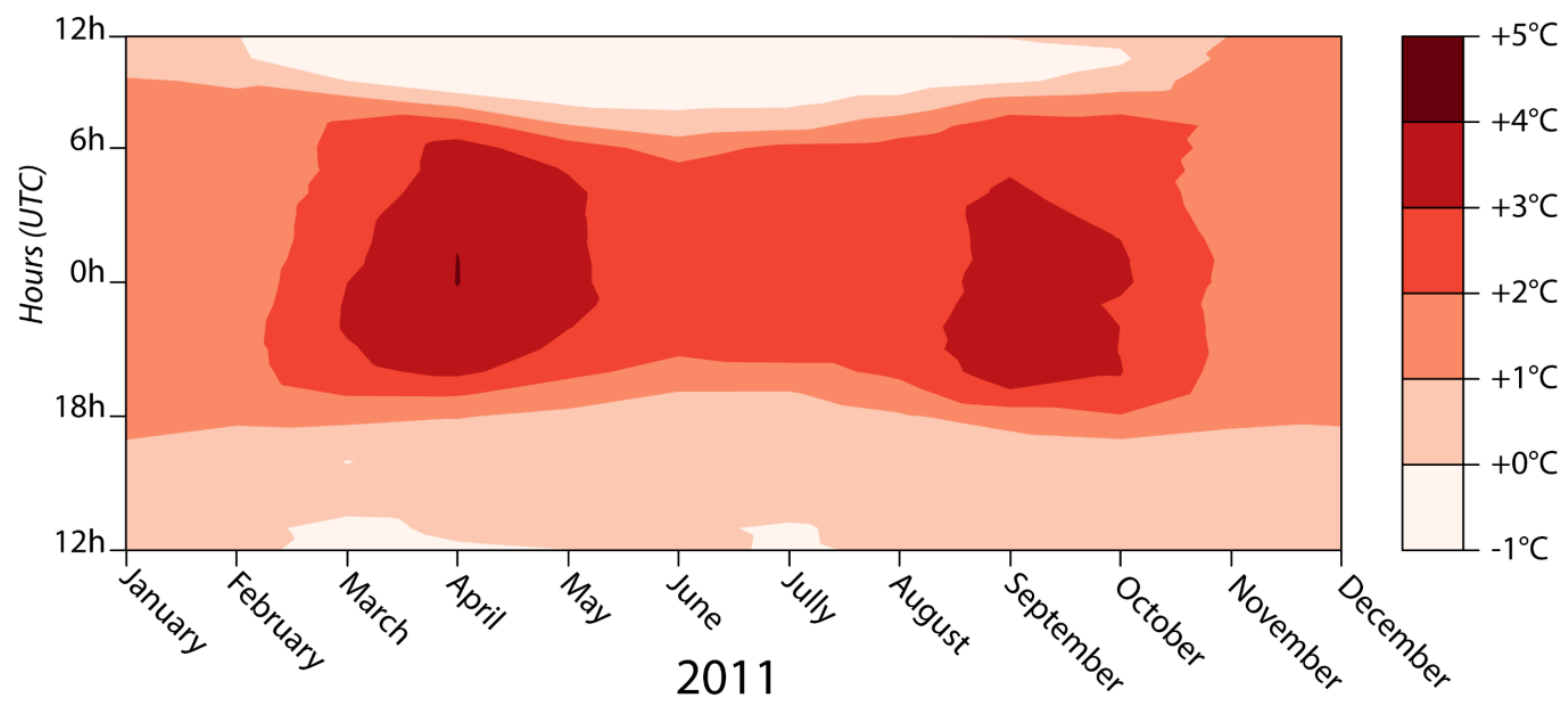

Figure 3, Average temperature difference between the center (Griffon) and the rural site (Melesse) according to the time (Coordinated Universal Time) and months during 2011.

measurement sites according to the phenomenon.

For mapping the UHI, $\Delta \mathrm{Tn}$ between each station and the rural reference (Melesse) spatially modeled. The multiple linear regression deals with an estimation of associated errors. In addition, the regression method defines the relevant estimators among environmental factors.

\subsubsection{Land use variables}

The multi-criteria method of mapping the UHI required exhaustive and homogenous information on the land use. The GIS services of "Rennes Métropole" provided data about buildings. This database supplied information about the buildings' floor area and height. Similarly, the municipality supplied information on public roads, water areas, altitude (from a digital terrain model) and public vegetation areas. Vegetation is usually well-known information for public areas, however this information is mostly incomplete for private areas. In this study, we completed this private vegetation information from a RapidEye satellite image. This image was dated July 2010 with a resolution of $5 \times 5 \mathrm{~m}$. The object-oriented approach was used to extract the vegetation classification and the Kappa coefficient was above 0.9 (Hay and Castilla, 2008; Nabucet et al., 2015). In this way, we identified agricultural land, trees and herbaceous vegetation.

Using this classification, we obtained variables from several calculated metrics: built-up cover, impervious surfaces, high vegetation cover, low vegetation cover, water surfaces, height of buildings, distance to center and altitude. The land use fraction was calculated for different sizes of buffer. The influence of the land use on the temperature is a fluctuating footprint. Therefore the field of view of 
the thermal sensor forms a disc with a radius of between $100 \mathrm{~m}$ and $1 \mathrm{~km}$ according to the building density (Amorim et al., 2015; Schmid et al., 1991; Voogt and Oke, 2003; Yoshino, 1975). Usually the influence of buildings on air temperature is considered as a $500 \mathrm{~m}$ radius circ le (Eliasson and Svensson, 2003; Stewart and Oke, 2010; Suomi and Käyhkö, 2012; Zhao et al., 2011). We determined the radius sizes for $100 \mathrm{~m}, 200 \mathrm{~m}, 300 \mathrm{~m}, 400 \mathrm{~m}, 500 \mathrm{~m}, 600 \mathrm{~m}, 700 \mathrm{~m}, 800 \mathrm{~m}$ and $900 \mathrm{~m}$. This fluctuating buffer reflected the variation in the representativeness of the weather stations, extending from $100 \mathrm{~m}$ to $1 \mathrm{~km}$ (Amorim et al., 2015; Kljun et al., 2002; Oke, 2006; Voogt and Munn, 2002). In accordance with atmospheric conditions, the method aimed to define the scale of the surrounding area influencing the UHI. The maximum radius was $900 \mathrm{~m}$ in order to limit the overlapping rate between buffers to an average of $18 \%$ with a maximum rate of $70 \%$. The buffers overlap led to enhance the risk of spatial autocorrelation. Hence the method took into account the spatial variability of the UHI due to seasons and weather types (Suomi et al., 2012).

\subsubsection{Building a regression model}

The first step of the process was to build a regression model by selecting explanatory variables (Figure 4), that explained the UHI variability. This method was automatized to test the overall combinations of predictors by the exhaustive method. This process was computed with $\mathrm{R}$ software and the tool regsubsets() available in leaps library (Miller, 2002). It explored all the combinations available, then it compared and classified according to a predefined criteria. This methodology could require an extended performance to compute numerous variables due to the $2^{\mathrm{p}}-1$ models ( $\mathrm{p}=$ number of variables). Here the number of models to compare was $2^{65}-1$ regressions. However, we previously removed the poorly correlated variables and we selected a maximum of 3 variables per model $(p \leq 3)$, which significantly reduced the process. The poorly correlated variables were excluded from the process if there were not significant ( $\mathrm{p}$-value>0.01) according to the Bravais-Pearson test (R). Then the BIC

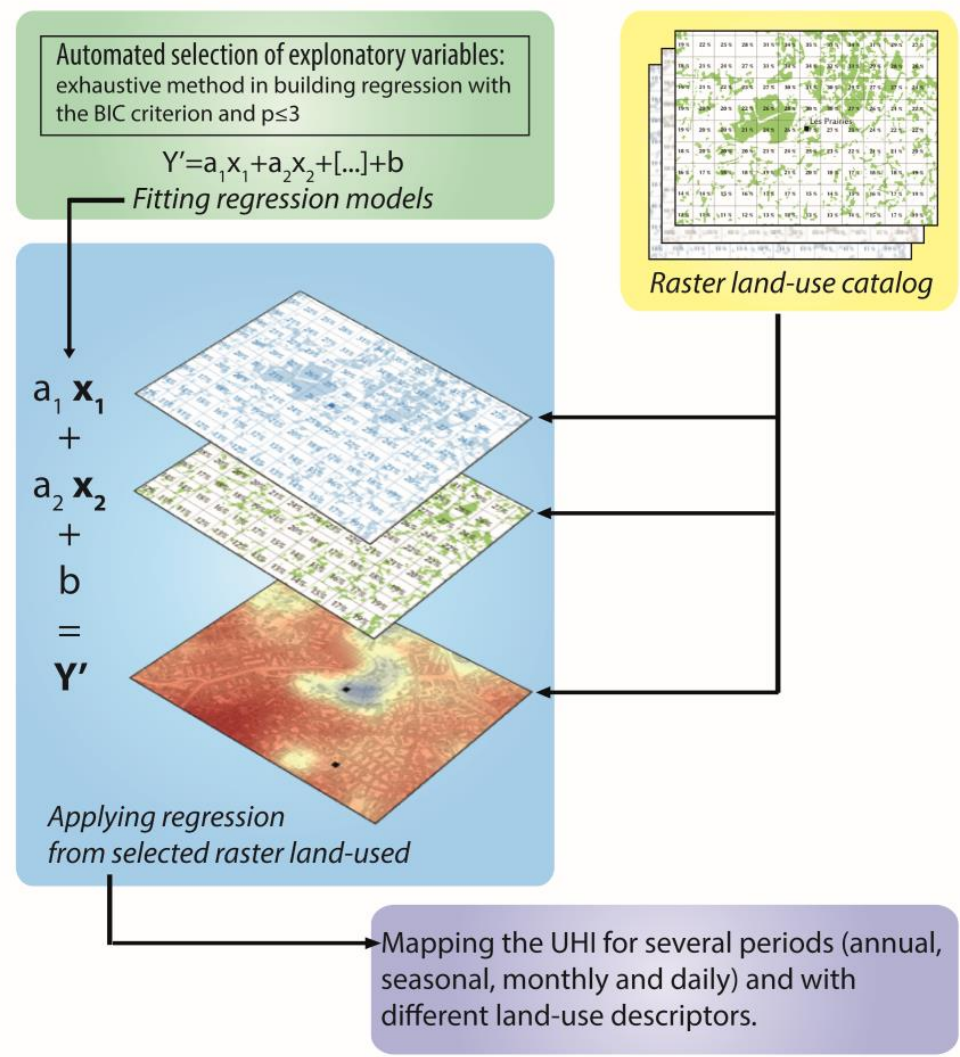

Figure 4, Methodfor mapping the UHI with linear regression ( $p=$ number of predictive variables). 
(Bayesian Information Criterion) was used to rank the regression models (Akaike, 1973). This criterion fitted models by maximizing likelihood, therefore it reduced the number of predictors.

The second step of the process was to execute the selected regression during the first step. The explanatory variables were prepared in a raster $100 \times 100 \mathrm{~m}$ grid resolution, corresponding to the local scale in an urban context (Oke, 2006). This grid was composed of 90,000 cells for Rennes Metropole (i.e. $900 \mathrm{~km}^{2}$ ). Each land use descriptor was converted into a raster according to the "moving window" method. Hence the land use metrics were processed for each cell with the preselected buffer radius. For example, the total vegetation fraction included in a buffer size of $400 \mathrm{~m}$ was calculated with a radius of $400 \mathrm{~m}$ from the cell center. Step by step, the cells made up the raster corresponding to the total vegetation within a $400 \mathrm{~m}$ radius.

We thereby produced a raster catalog with 65 descriptive variables. After the step model selection, we applied the regression coefficients to the associated raster. Following this method, the UHI mapping was also produced for different periods (annual, seasonal, monthly and daily).

\section{Results}

\subsection{Spatial variability of the UHI in Rennes}

The analysis dealt with the $\mathrm{T}_{\min }$ measured by the 22 weather stations in the presence of the UHI (89 days in 2011), which corresponded to 1958 preselected observations. The AHC (Agglomerative Hierarchical Clustering) using the Ward method shows that $72 \%$ of the variance was explained by three main classes (noted C1, C2 and C3 in Figure 5).

The C1 class corresponded to the center neighborhood, for instance the sites of Griffon and Les Champs Libres associated with LCZ 2. The dendrogram (Figure 5) shows that the C3 class was linked to $\mathrm{C} 1$, and $\mathrm{C} 3$ was subdivided into $\mathrm{C} 3 \mathrm{a}$ and $\mathrm{C} 3 \mathrm{~b}$. This $\mathrm{C} 3$ class gathered the weather stations placed in the urban area. Moreover, the $\mathrm{C} 3 \mathrm{a}$ sites were located on the edge of the center, while the $\mathrm{C} 3 \mathrm{~b}$ stations

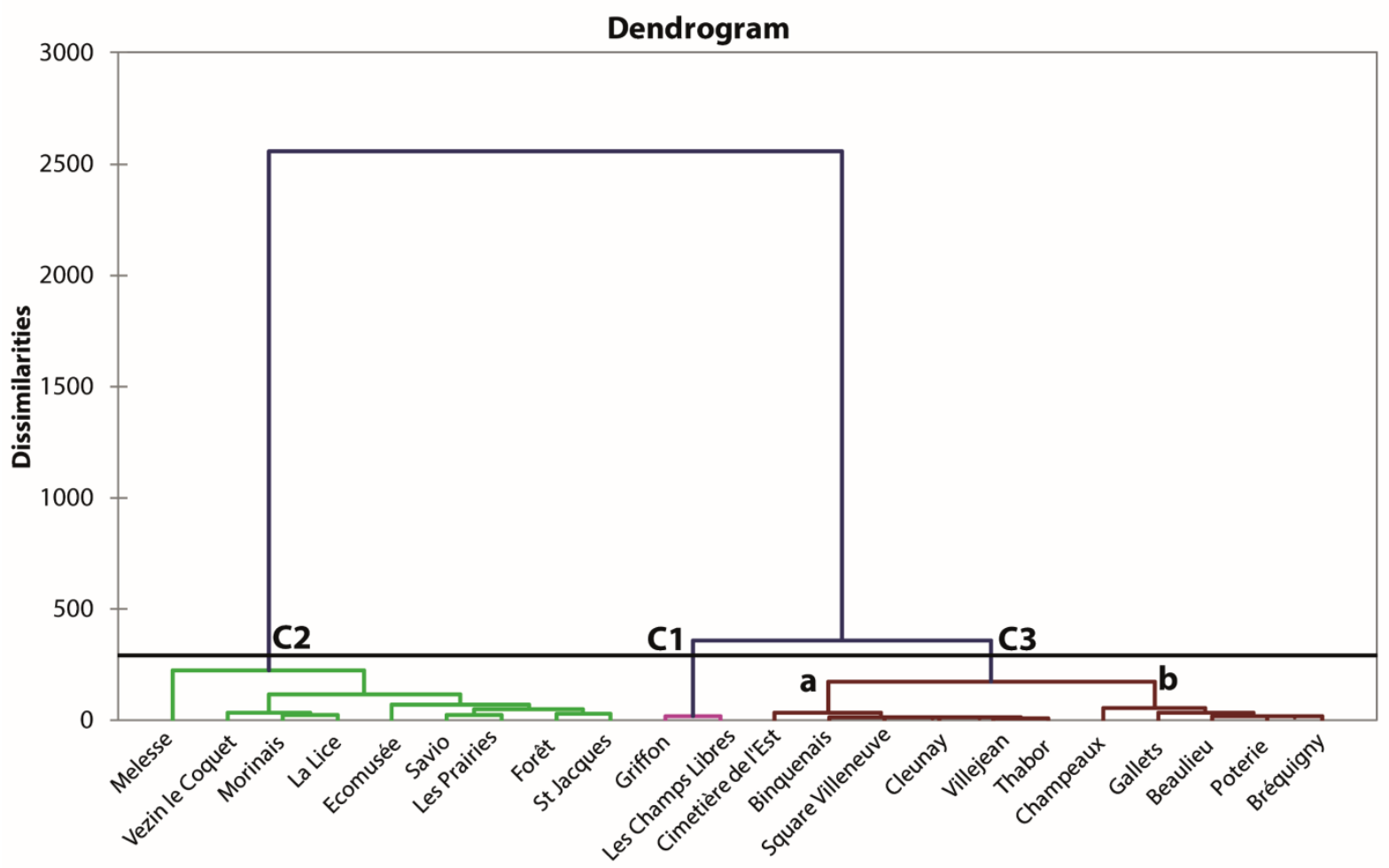

Figure 5, Siting classification (AHC method) for minimum temperature. Four classes: $C 1, C 2, C 3 a$, $C 3 b$. 
were sited around them. The C3a class was characterized by sites which were frequently classed LCZ 5 and the C3b sites were often classified LCZ 6. Usually, the C3 sites were situated in the suburban area. The $\mathrm{C} 2$ class comprised the sites located in a rural context or in surrounding small towns. All the sites of $\mathrm{C} 2$ were defined as LCZ 9. However, AHC classified Les Prairies as a site belonging to C2, which meant that the UHI does not affect this urban park.

The classification according the AHC showed some connection between the temperature observed and the environmental characteristics (Figure 6). The three classes indicated different ranges of UHI intensity. The class of the stations in the center (C1) measured the highest UHI with $\Delta \mathrm{T}_{\min }>4^{\circ} \mathrm{C}$. The C3 class was composed of the other sites in the urban area and the UHI was moderate, with $2.5^{\circ} \mathrm{C} \leq \Delta \mathrm{T}_{\min } \leq 4.0^{\circ} \mathrm{C}$. For the class $\mathrm{C} 2$ located in the rural context, the UHI intensity was weak or absent, $\Delta \mathrm{T}_{\min }<2.5^{\circ} \mathrm{C}$.

2.2 Applying the model to map UHI average in 2011

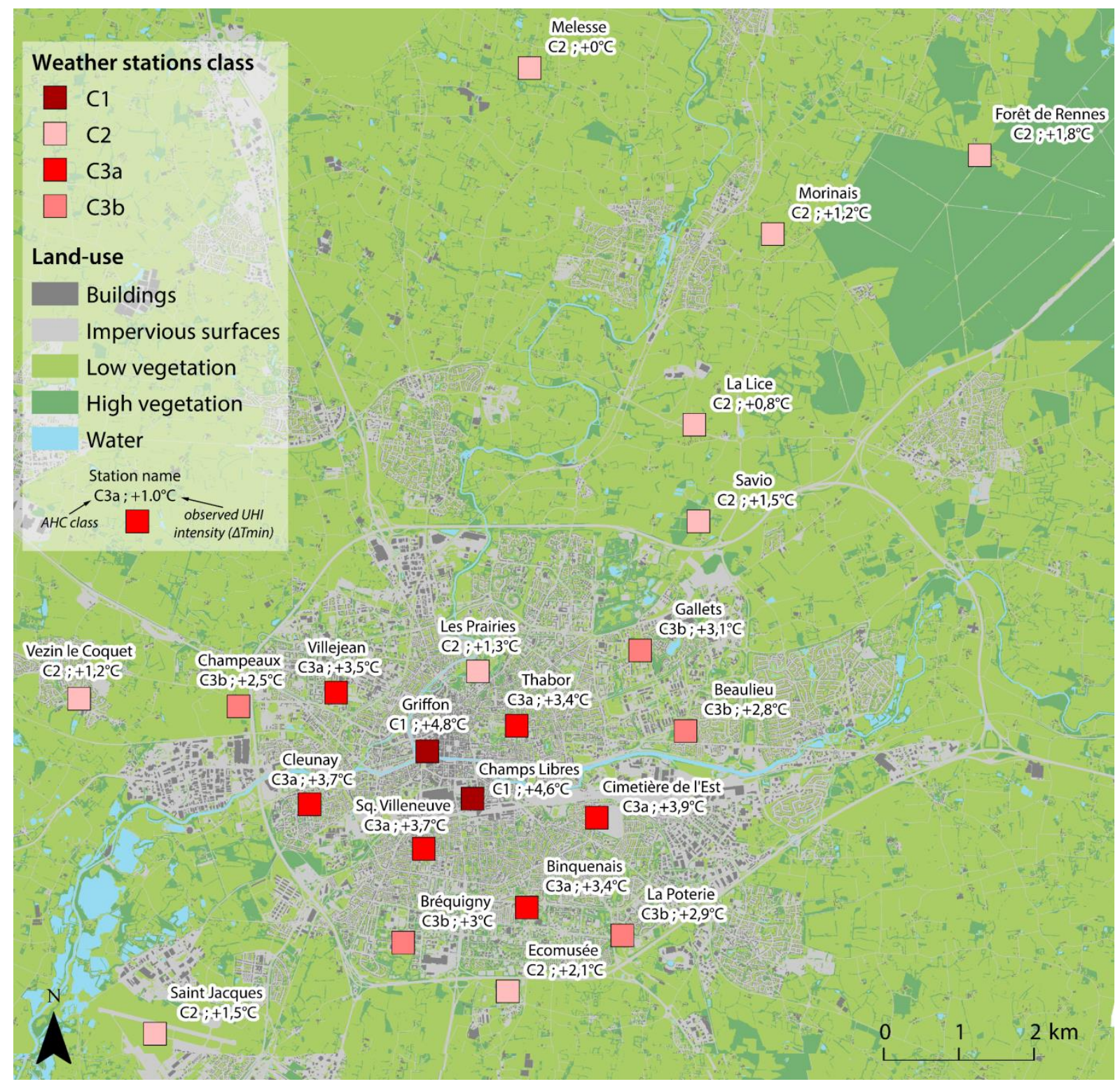

Figure 6, Clustering (AHC) the weather stations (Figure 5) and the UHI (2011) observed in the metropolitan area of Rennes.

Using the UHI measurements recorded in 2011, the aim was to map air temperature according to the selected regression model. The first step was to determine the explanatory variables by a correlation 
matrix with the UHI average in 2011. Table 2 shows the four most correlated land uses with the UHI for each size of buffer radius $(100 \mathrm{~m}$ to $900 \mathrm{~m})$. The most correlated variables had a buffer radius greater than or equal to $300 \mathrm{~m}$ for $\mathrm{R}=0.85$.

Table 2, Correlation between the UHI in 2011 and land use according to buffer size. The highest degree of correlation for each land use is shown in bold.

\begin{tabular}{|l|c|c|c|c|c|c|c|c|l|}
\hline $\begin{array}{l}\text { Fraction of land use / } \\
\text { Buffer radius (m) }\end{array}$ & 100 & 200 & 300 & 400 & 500 & 600 & 700 & 800 & 900 \\
\hline Vegetation & -0.81 & -0.84 & -0.86 & -0.85 & -0.85 & -0.87 & -0.87 & -0.87 & $\mathbf{- 0 . 8 8}$ \\
\hline Low vegetation & -0.76 & -0.79 & -0.82 & -0.83 & -0.84 & -0.85 & -0.86 & -0.86 & $-\mathbf{0 . 8 7}$ \\
\hline Built-up & 0.69 & 0.81 & $\mathbf{0 . 8 3}$ & 0.82 & 0.82 & 0.82 & $\mathbf{0 . 8 3}$ & $\mathbf{0 . 8 3}$ & 0.82 \\
\hline Impervious & 0.71 & 0.77 & 0.80 & 0.79 & 0.78 & 0.83 & 0.83 & 0.84 & $\mathbf{0 . 8 5}$ \\
\hline
\end{tabular}

After using the methodology described in section 1.4.2, the UHI observed in 2011 was mapped by applying the following linear regression model (Figure 7):

\section{Equation $1 \Delta$ Tn $2011=3,20-0.029 \times B 900$ Low vegetation $+0.044 \times B 200$ Built}

This model explained $82 \%\left(\mathrm{R}^{2}{ }_{\text {adj }}\right)$ of spatial variability and the RMSE was 0.54 . The selected factors were the fraction of low vegetation in a $900 \mathrm{~m}$ radius buffer and the built-up cover in a $200 \mathrm{~m}$ radius buffer. These variables were weakly correlated together $(\mathrm{R}=-0.69)$ in comparison to the correlation with the UHI. The Durbin-Watson ${ }^{1}$ index showed the absence of autocorrelation with residuals (DW=1.87) (Durbin and Watson, 1950). The UHI is illustrated on the map based on the regression method (Figure 4). The UHI intensity varied from $+0.3^{\circ} \mathrm{C}$ to $+5.8^{\circ} \mathrm{C}$. The spatial distribution of residual data reveals the precision of the model (Figure 7). Hence, the residuals of 18 stations were under $\pm 0.5^{\circ} \mathrm{C}$ which is equal to the measurement accuracy of the weather stations. The station Les Prairies has the highest residual with $+1.5^{\circ} \mathrm{C}$. The specific environment of this site could explain this overestimation. Les Prairies is in the biggest urban park of the city with an area of 30 ha. This site is slightly steep-sided with an area of wetland, which could expla in the low UHI measured. The residual for five sites was between $0.5^{\circ} \mathrm{C}$ and $1{ }^{\circ} \mathrm{C}$ including the forest site (Forêt). We observed a nocturnal hot spot due to the radiation shield by the covering forest canopy (Geiger, 1950; Raynor, 1971; Stoutjesdijk and Barkman, 2014; Van der Poel and Stoutjesdijk, 1959). Even although the temperature estimated for this station was correct, we could not deduce that the model is able to take into account this phenomenon. The variables used by the model were low vegetation and built-up fractions, while the forest area was considered as high vegetation. Thus, this area formed a "forest heat island" by the model. The network of weather stations was not suitable, and it is therefore important to consider the modeling of the temperature in the forest area as irrelevant.

\subsection{Analysis of the UHI pattern}

\subsubsection{Seasonal comparisons}

To observe the spatial variability of the UHI according to the seasons, we applied the same regression model (Figure 4) selecting the same variables. The variance explained by the model depended on the season such as this order of adjusted $\mathrm{R}^{2}\left(\mathrm{R}^{2}{ }_{\text {adj }}\right)$ : winter $\left(\mathrm{R}^{2}{ }_{\text {adj. }}=0.88\right)$, spring $\left(\mathrm{R}^{2}{ }_{\text {adj }}=0.84\right)$, summer $\left(\mathrm{R}^{2}{ }_{\text {adj. }}=0.80\right)$ and fall $\left(\mathrm{R}^{2}\right.$ adj. $\left.=0.75\right)$. These differences could be explained by the number of days with a UHI. The UHI average in winter concerned only 10 days, therefore the UHI pattern was more homogeneous than in the other seasons. In comparison, fall, spring and summer had respectively 21 , 30 and 28 days with a UHI. However, fall had the lowest score in terms of its explanation by the

\footnotetext{
${ }^{1}$ Durbin-Watson index shows that the errors were uncorrelated. If we chose a significance level $\alpha=0.01$, observations $n=22$ and regressors $k=2$, the Durbin-Watson table gave $d 1=0.915$ and $d 2=1.284$. The DurbinWatson value of Equation $1(\mathrm{DW}=1.87$ ) was included between $\mathrm{d} 2<1.87<4-\mathrm{d} 2$, thus it meant no autocorrelated errors.
} 
model. The wind could not explicate a hypothetical UHI pattern shift because the daily average wind was $2.3 \mathrm{~m} . \mathrm{s}^{-1}$ in fall versus $2.6 \mathrm{~m} . \mathrm{s}^{-1}$ in the other seasons.

The RMSE was higher for the summer period with 0.64 and the residuals took place at similar stations to the spring and fall. The greatest residual value was the site Les Prairies with $-1.6^{\circ} \mathrm{C}$ in spring, $1.8^{\circ} \mathrm{C}$ in summer and $-1.2^{\circ} \mathrm{C}$ in fall. This result showed the overestimation of the UHI in this urban park for each season modeled.

The UHI map (Figure 8) shows the spatial variability according to the seasons. The intensity corresponds to four intervals of temperature difference with the rural site (Melesse): $\left[0^{\circ} \mathrm{C} ;+2^{\circ} \mathrm{C}\right]$, $\left[+2^{\circ} \mathrm{C} ;+3^{\circ} \mathrm{C}\right],\left[+3^{\circ} \mathrm{C} ;+4^{\circ} \mathrm{C}\right]$ and $\left[+4^{\circ} \mathrm{C} ;+6^{\circ} \mathrm{C}\right]$. These thresholds determine the difference in the intensive UHI in the center of the city in comparison with the UHI in suburban areas. The UHI intensity increased from winter to summer. The intensive UHI $\left(\Delta \mathrm{T}_{\min } \geq 4.0^{\circ} \mathrm{C}\right)$ spread around the central neighborhood and the UHI intensity rose for all urban stations, except for the urban park (Les Prairies) which recorded a "cool is land". Meanwhile, the UHI increased in the sites close to the urban

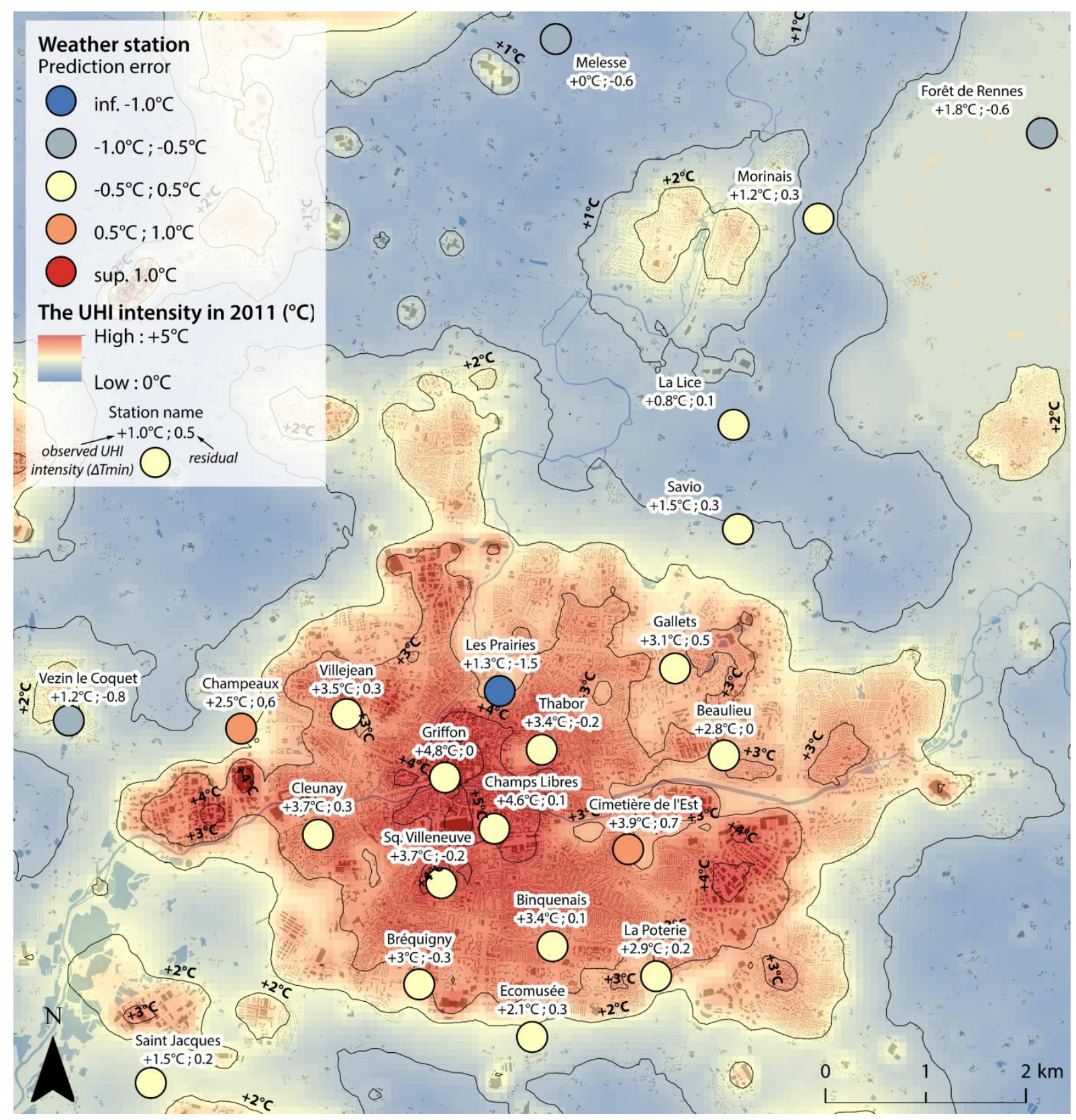

Figure 7, Mapping the UHI in 2011: patterns and model assessment. 
area of Rennes (i.e. Ecomusée, St Jacques, Champeaux and Savio), while the weather stations located in rural areas did not show any significant change. These seasonal contrasts between weather stations could be due to the nearby environment of each site. This effect is due to tree cover and anthropogenic heat, among other factors (Stewart and Oke, 2012). In this way, in the urban park (Les Prairies) a low

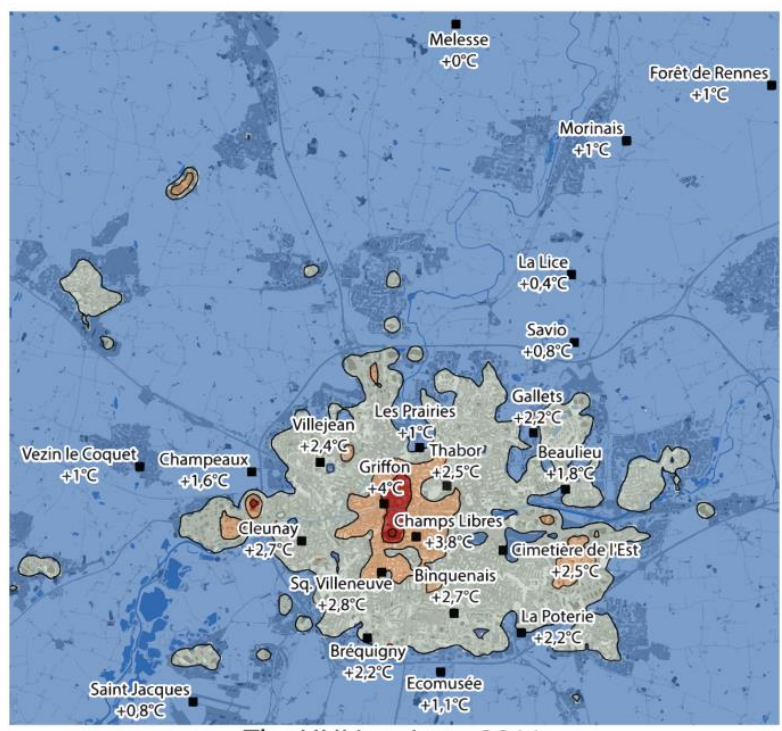

The UHI in winter 2011

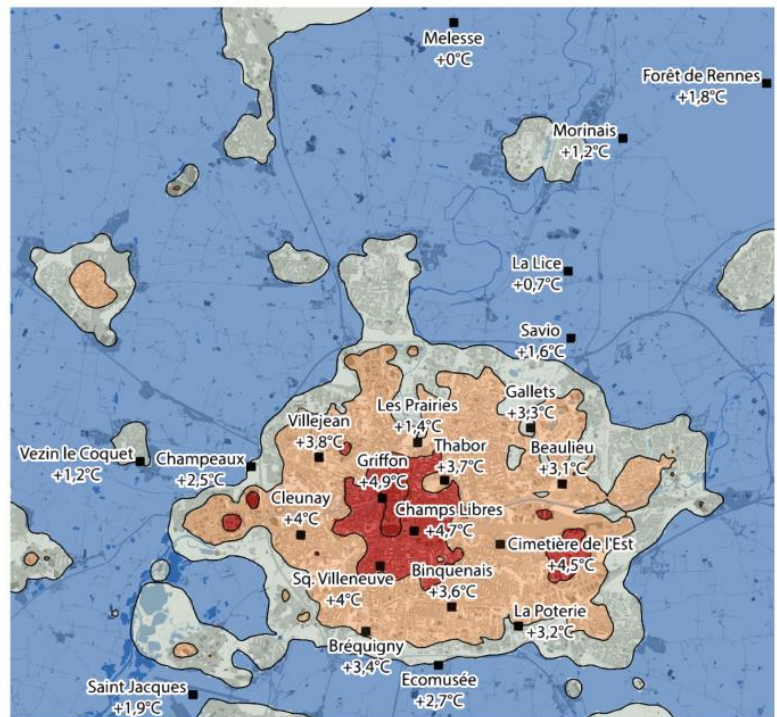

The UHI in summer 2011

- Weather station (observation)

The UHI intensity

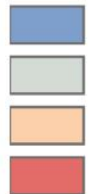

Land-use

Buildings

$0^{\circ} \mathrm{C} ;+2.0^{\circ} \mathrm{C}$

$+2.0^{\circ} \mathrm{C} ;+3.0^{\circ} \mathrm{C}$

$+3.0^{\circ} \mathrm{C} ;+4.0^{\circ} \mathrm{C}$

$+4.0^{\circ} \mathrm{C} ;+5.0^{\circ} \mathrm{C}$

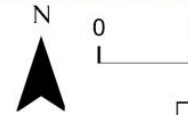

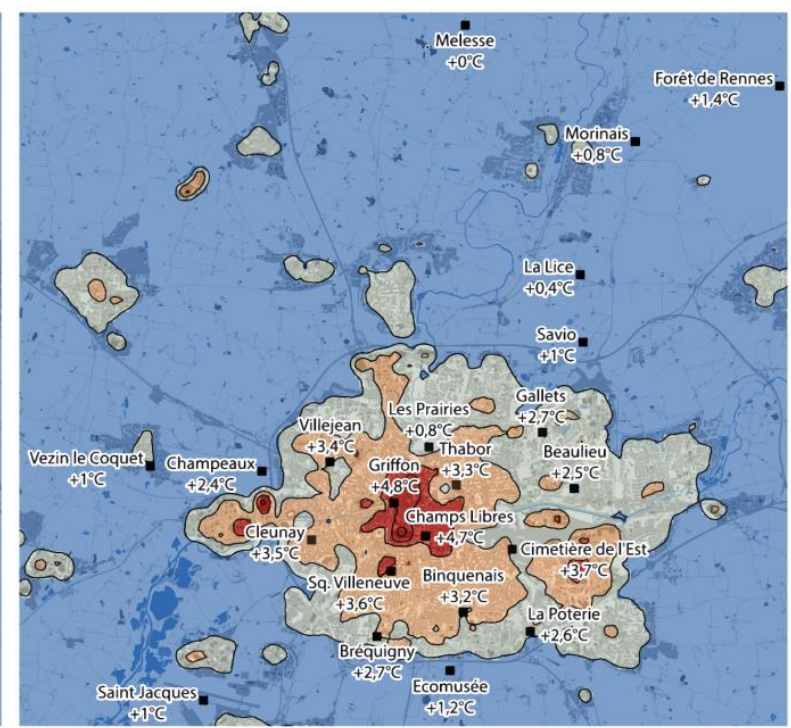

The UHI in spring 2011

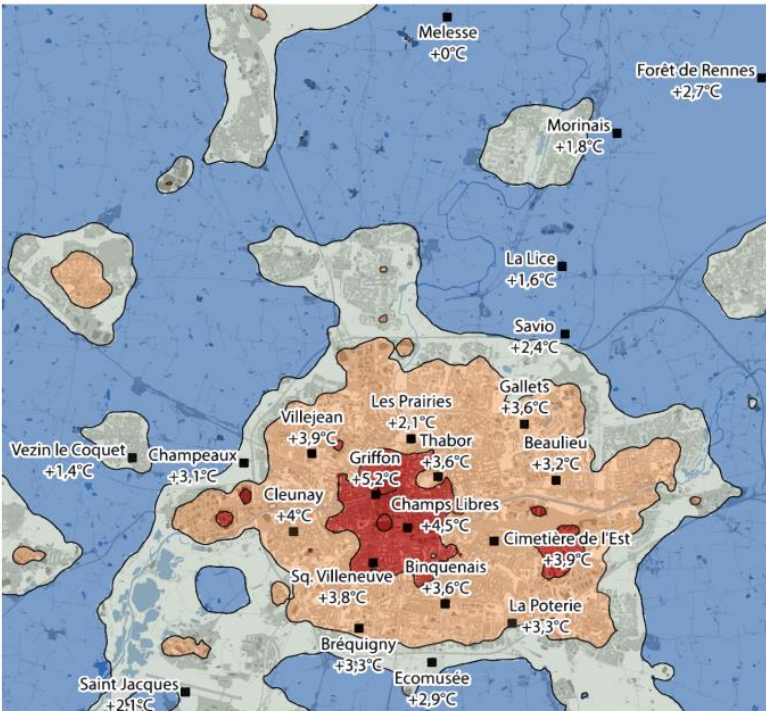

The UHI in fall 2011

$4 \mathrm{~km}$

\begin{tabular}{|l|llll|}
\hline Model/Season & Winter & Spring & Summer & Fall \\
\hline Day with UHI & 10 & 30 & 28 & 21 \\
$\mathrm{R}_{\text {ajusted }}^{2}$ & 0.88 & 0.84 & 0.80 & 0.75 \\
RMSE & 0.36 & 0.57 & 0.64 & 0.59 \\
\hline
\end{tabular}

Figure 8, Seasonality of the UHI intensity and model assessment.

UHI intensity was observed in winter in comparison with the absence of UHI in summer. This difference suggests higher evapotranspiration in summer by plant activity compared to winter.

From summer to fall, the UHI in Rennes was similar $\left(\Delta \mathrm{T}_{\min } \geq 2^{\circ} \mathrm{C}\right)$ but it extended to the close surrounding city. The stations in this neighboring area recorded an increase in UHI intensity, such as $S t$ Jacques and Savio with $\Delta \mathrm{T}_{\min } \geq 2.0^{\circ} \mathrm{C}$. The station in the forest showed that the difference in 
in accordance with the specific weather conditions in September and October 2011. The

extended into these months with a high average maximum temperature above $+2.5^{\circ} \mathrm{C}$ and while the record maximum temperature was beaten on October $2^{\text {nd }}\left(\mathrm{T}_{\max }=30^{\circ} \mathrm{C}\right)$.

\subsubsection{Estimating the daily UHI with the land use variables}

To compare various types of weather conditions, we applied our method to the daily UHI in 2011. $\mathrm{T}$ adjusted $\mathrm{R}^{2}$ values of the models ranged from 0.33 to 0.87 with an average of 0.71 . For the daily in winter, spring and summer, the average of $\mathrm{R}^{2}$ score was 0,74 and 0,63 in fall. These results we similar to Gothenburg (Eliasson and Svensson, 2003). For 89 days with UHI presence, 57 day

$64 \%$ ) had an adjusted $\mathrm{R}^{2}$ greater than 0.7. Finally, 22 land use variables from a total of 65 were us map the UHI. We processed the occurrence of these variables. Low vegetation within a radius of 9 was the most selected variable for the models. It was retained for $30 \%$ of days with UHI and mainly used as a unique variable and exclusively associated with the built-up fraction. The se most selected variable was the built-up fraction for a buffer with a radius of $100 \mathrm{~m}$ and $200 \mathrm{~m}$. It used for $15 \%$ of models and every time it was selected with another variable, which was often vegetation cover or impervious surfaces. These variables provided additional information for regression. Finally, impervious surfaces and total vegetation within a radius of $900 \mathrm{~m}$ were chosen for $9 \%$ of models; the method selected the other variables a few times. Total vegetation almost systematically retained for simple linear regressions. It corresponded to the simple descrip of the urban area, in other words, it was connected to the degree of urbanization. The total vegeta fraction variable fitted the model often with a radius of $900 \mathrm{~m}, 300 \mathrm{~m}$ and $200 \mathrm{~m}$. The land frequently selected for the daily UHI in 2011 were, in order, the low vegetation fraction (33\%), built-up fraction (32\%), the total vegetation (18\%), the impervious fraction $(15 \%)$ and the ave building height $(2 \%)$.

\section{Dis cussion \& Conclusion}

The variables linked to vegetation were used for $51 \%$ of daily models, which highlights importance of vegetation in explaining the UHI (Davis et al., 2016; Suomi et al., 2012). However, low vegetation fraction was a more relevant descriptor than high vegetation and appeared more oft than the total vegetation fraction. This result does not mean that trees had a lower influence on UHI; on the contrary, they have a higher evapotranspiration capacity than grassed surfaces. So studies focusing on the effect of trees on the UHI have shown the micro-local influence of trees (fo buffer zone of 40m) (Rafiee et al., 2016). Other studies have emphasized the greater efficiency of type of vegetation to decrease the temperature at the micro-local scale (Lin et al., 2008; 2013). In our study, the absence of high vegetation (trees) as an explained variable was Rennes Metropole scale. Thus, the rural sites showed a great variability, with the high fraction fluctuating between $6 \%$ and $69 \%$. On the other hand, the correlation between vegetation fraction and the UHI observed in the intra-urban area (composed of 13 weather $\mathrm{s}$ the city) was significant with $R=-0.79$ versus $R=0.1$ on the Rennes Metropole scale.

The analysis of the relations hip between the land cover factors and the intensity of the UHI a to evaluate their potential role in mitigating the UHI phenomenon. However, the adaptation o to heat waves by mitigating the UHI phenomenon calls for various solutions which have to account the geographical context: i.e. topoclimatic elements (relief, forest, lake and sea), the future methods of urban development, and the demographic dynamics (Bowler et al., 20 adaptation of the city to heat waves by mitigating the UHI calls for various solutions which account this geographical context. 
Our results show the main variables contributing to the identification of indexes for the formulation of prescriptions in order to attenuate the UHI at the neighborhood level. The land use fraction could be used as a decision-making tool for the attenuation of the UHI phenomenon (Gill et al., 2008; Ng et al., 2012). It allows a combination of land use fractions to be defined for a given UHI intensity. This point could be further elaborated by the projection of the UHI from different management scenarios. These scenarios could include the densification of built-up areas, several degrees of greening by vegetation, and different forms of extensive urban sprawl. The application of models after land use change is a method to evaluate UHI growth (Lemonsu et al., 2015). These scenarios illustrate the importance of urban planning documents and their orientations for evaluating the future urban climate. We emphasize that local climate scale has to be taken into account and the development strategies must therefore correspond to this neighborhood scale (between $100 \mathrm{~m}$ and $1 \mathrm{~km}$ ). Despite the numerous uncertainties associated with urban projects and the model, a scale fitted to these projections retains this variability and provides guidance for decision-making for the city studied.

The results showed the dependence of the UHI to land use for different scales. In this study, the footprint scales of the main factors extended to $900 \mathrm{~m}$ for low vegetation fraction and to $100-200 \mathrm{~m}$ for built fraction. However, the LCZ classification generally uses a fix scale of $200 \mathrm{~m}$ context. This means that there is UHI intensity variability within the same class. Furthermore, LCZ demarcation become unclear especially within a mixed urban form, the land use fraction could be considered in such case. In next studies, we will explore the similarities and differences of the LCZ according to the UHI intensity and the land use scales associated.

\section{Acknowledgements}

This study was supported by Rennes Métropole (Municipality) and it was performed by the UMR LETG 6554 with the CNRS and the Zone Atelier Armorique (ZAA).

\section{References}

Akaike, H., 1973. Maximum likelihood identification of Gaussian autoregressive moving average models. Biometrika 60, 255-265.

Alcoforado, M.-J., Andrade, H., Lopes, A., Vasconcelos, J., 2009. Application of climatic guidelines to urban planning. Landsc. Urban Plan. 90, 56-65. https //doi.org/10.1016/j.landurbplan.2008.10.006

Amorim, M.C. de C.T., Dubreuil, V., Cardoso, R. dos S., 2015. Modelagem espacial da ilha de calor urbana em presidente prudente (SP) - Brasil. Rev. Bras. Climatol. 16, 29-45.

Amorim, M.C. de C.T., Dubreuil, V., Quenol, H., Neto, J.L.S., 2009. Características das ilhas de calor em cidades de porte médio: exemplos de Presidente Prudente (Brasil) e Rennes (França). Confin. Rev. Fr. géographie/Revista Fr. Geogr.

Besancenot, J.-P., 2002. Vagues de chaleur et mortalité dans les grandes agglomérations urbaines. Environnement, risques $\backslash \&$ santé 1, 229-240.

Bottyan, Z., Unger, J., 2003. A multiple linear statistical model for estimating the mean maximum urban heat island. Theor. Appl. Climatol. 75, 233-243. https://doi.org/10.1007/s00704-0030735-7

Bowler, D.E., Buyung-Ali, L., Knight, T.M., Pullin, A.S., 2010. Urban greening to cool towns and cities: A systematic review of the empirical evidence. Landsc. Urban Plan. 97, 147-155. https $/ /$ doi.org/10.1016/j.landurbplan.2010.05.006 
Cantat, O., 2004. L'îlot de chaleur urbain parisien selon les types de temps. Norois 191, 1-37.

Chow, W.T.L., Roth, M., 2006. Temporal dynamics of the urban heat island of Singapore. Int. J. Climatol. 26, 2243-2260. https://doi.org/10.1002/joc.1364

Davis, A.Y., Jung, J., Pijanowski, B.C., Minor, E.S., 2016. Combined vegetation volume and "greenness" affect urban air temperature. Appl. Geogr. 71, 106-114. https $/ /$ doi.org/10.1016/j.apgeog.2016.04.010

de Munck, C., Pigeon, G., Masson, V., Meunier, F., Bousquet, P., Tréméac, B., Merchat, M., Poeuf, P., Marchadier, C., 2012. How much can air conditioning increase air temperatures for a city like Paris, France? Int. J. Climatol. 227, n/a-n/a. https://doi.org/10.1002/joc.3415

Dubreuil, V., Montgobert, M., Planchon, O., 2002. Une méthode d'interpolation des températures de l'air en Bretagne : combinaison des paramètres géographiques et des mesures infrarouge NOAAAVHRR. Hommes Terres Nord 26-39.

Dubreuil, V., Quénol, H., Foissard, X., Planchon, O., 2011. Climatologie urbaine et îlot de chaleur urbain à Rennes, in: Ville et Biodiversité : Les Enseignements d'une Recherche Pluridisciplinaire. pp. 137-159.

Durbin, J., Watson, G.S., 1950. Testing for serial correlation in least squares regression: I. Biometrika $37,409-428$.

Eliasson, I., Svensson, M.K., 2003. Spatial air temperature variations and urban land use - a statistical approach. Meteorol. Appl. 10, 135-149. https://doi.org/10.1017/S 1350482703002056

Erell, E., Williamson, T., 2007. Intra-urban differences in canopy layer air temperature at a midlatitude city. Int. J. Climatol. 27, 1243-1255. https://doi.org/10.1002/joc.1469

Eveno, M., Planchon, O., Oszwald, J., Dubreuil, V., Quénol, H., Maëlle, E., Planchon, O., Johan, O., Dubreuil, V., Quénol, H., 2016. Variabilité et changement climatique en France de 1951 à 2010: analyse au moyen de la classification de Köppen et des "types de climats annuels". Climatologie 13, 47-70. https:/doi.org/10.4267/climatologie.1203

Fenner, D., Meier, F., Scherer, D., Polze, A., 2014. Spatial and temporal air temperature variability in Berlin, Germany, during the years 2001-2010. Urban Clim. 10, 308-331. https:/doi.org/10.1016/j.uclim.2014.02.004

Foissard, X., Cantat, O., Dubreuil, V., Savouret, E., Quénol, H., Bensaid, A., Planchon, O., others, 2012. Climat urbain, changement climatique et types de temps dans le Grand Ouest de la France, in: Changement Climatique Dans l'Ouest. pp. 73-92.

Gabriel, K.M. a, Endlicher, W.R., 2011. Urban and rural mortality rates during heat waves in Berlin and Brandenburg, Germany. Environ. Pollut. 159, 2044-2050. https//doi.org/10.1016/j.envpol.2011.01.016

Geiger, R., 1950. The Climate Near The Ground, 2nd Editio. ed, Harvard Universty Press. Cambridge, MA.

Gill, S.E., Handley, J.F., Ennos, A.R., Pauleit, S., Theuray, N., Lindley, S.J., 2008. Characterising the urban environment of UK cities and towns: A template for landscape planning. Landsc. Urban Plan. 87, 210-222. https://doi.org/10.1016/j.landurbplan.2008.06.008

Hartmann, D.L., Tank, A., Rusticucci, M., 2013. IPCC fifth assessment report, climate change 2013: The physical science basis. IPCC AR5 31-39.

Hay, G J, Castilla, G., 2008. Geographic Object-Based Image Analysis (GEOBIA): A new name for a new discipline, in: Blaschke, T., Lang, S., Hay, Geoffrey J (Eds.), Object-Based Image Analysis: Spatial Concepts for Knowledge-Driven Remote Sensing Applications. Springer Berlin Heidelberg, Berlin, Heidelberg, pp. 75-89. https://doi.org/10.1007/978-3-540-77058-9_4 
Hidalgo, J., Masson, V., Gimeno, L., 2010. Scaling the Daytime Urban Heat Island and Urban-Breeze Circulation. J. Appl. Meteorol. Climatol. 49, 889-901. https://doi.org/10.1175/2009JAMC2195.1

Karl, T.R., Nicholls, N., Ghazi, A., 1999. CLIVAR/GCOS/WMO Workshop on Indices and Indicators for Climate Extremes - Workshop summary, in: Climatic Change. pp. 3-7. https $/ /$ doi.org/10.1023/A:1005491526870

Kazimierz, K., Fortuniak, K., 1999. Temporal and spatial characteristics of the urban heat island of Lodz, Poland. Atmos. Environ. 33, 3885-3895.

Kim, Y.-H., Baik, J.-J., 2002. Maximum Urban Heat Island Intensity in Seoul. Am. Meteorol. Soc. 651-659.

Kljun, N., Rotach, M.W., Schmid, H.P., 2002. Model for a Wide Range of Boundary-Layer. Boundary-Layer Meteorol. 103, 205-226.

Landsberg, H.E., 1981. The urban climate. Academic press.

Lemonsu, A., Viguié, V., Daniel, M., Masson, V., 2015. Vulnerability to heat waves: Impact of urban expansion scenarios on urban heat island and heat stress in Paris (France). Urban Clim. 14, $586-$ 605. https://doi.org/10.1016/j.uc lim.2015.10.007

Li, J., Heap, A.D., 2014. Spatial interpolation methods applied in the environmental sciences: A review. Environ. Model. Softw. 53, 173-189. https://doi.org/10.1016/j.envsoft.2013.12.008

Lin, B., Li, X., Zhu, Y., Qin, Y., 2008. Numerical simulation studies of the different vegetation patterns' effects on outdoor pedestrian thermal comfort. J. Wind Eng. Ind. Aerodyn. 96, 17071718. https://doi.org/10.1016/j.jweia.2008.02.006

Masson, V., 2000. A physically-based scheme for the urban energy budget in atmospheric models. Boundary-layer Meteorol. 94, 357-397.

Masson, V., Gomes, L., Pigeon, G., Liousse, C., Pont, V., Lagouarde, J.-P., Voogt, J., Salmond, J., Oke, T.R., Hidalgo, J., others, 2008. The canopy and aerosol particles interactions in Toulouse urban layer (CAPITOUL) experiment. Meteorol. Atmos. Phys. 102, 135-157.

Masson, V., Grimmond, C.S.B., Oke, T.R., 2002. Evaluation of the Town Energy Balance ( TEB ) Scheme with Direct Measurements from Dry Districts in Two Cities. Am. Meteorol. Soc. 10111026.

Middel, A., Häb, K., Brazel, A.J., Martin, C.A., Guhathakurta, S., 2014. Impact of urban form and design on mid-afternoon microclimate in Phoenix Local Climate Zones. Landsc. Urban Plan. 122, 16-28. https://doi.org/10.1016/j.landurbplan.2013.11.004

Miller, A., 2002. Subset selection in regression. CRC Press.

Morris, C., Simmonds, I., 2001. Quantification of the influences of wind and cloud on the nocturnal urban heat island of a large city. J. Appl. ... 169-182.

Nabucet, J., Rougier, S., Deniau, J., Vétillard, L., Hanson, E., Benarchid, O., Wolff, E., Hubert-Moy, L., Puissant, A., 2015. Multi-scale methodology to map grey and green structures in urban areas using Pléiades images and existing geographic data. Rev. Française Photogrammétrie Télédétection 95-101.

Ng, E., Chen, L., Wang, Y., Yuan, C., 2012. A study on the cooling effects of greening in a highdensity city: An experience from Hong Kong. Build. Environ. 47, 256-271. https $/ /$ doi.org/10.1016/j.buildenv.2011.07.014

Oke, T.R., 2006. Initial guidance to obtain representative meteorological observations at urban sites, World Meteorological Organization. 
Oke, T.R., 1987. Boundary Layer Climates. Routledge.

Oke, T.R., 1982. The energetic basis of the urban heat island. Q. J. R. Meteorol. Soc. 108, 1-24. https $/ /$ doi.org/10.1002/qj.49710845502

Oke, T.R., Maxwell, G.B., 1975. Urban heat island dynamics in Montreal and Vancouver. Atmos. Environ. 9, 191-200. https://doi.org/10.1016/0004-6981(75)90067-0

Pacifici, M., Rama, F., de Castro Marins, K.R., 2019. Analysis of temperature variability within outdoor urban spaces at multiple scales. Urban Clim. 27, 90-104. https $/ /$ doi.org/10.1016/j.uclim.2018.11.003

Peterson, T.C., Folland, C.C., Gruza, G., Hogg, W., Mokssit, A., Plummer, N., 2001. Report on the activities of the Working Group on Climate Change Detection and Related Rapporteurs 19982001. Rep. WCDMP-47, WMO-TD 1071. https://doi.org/WMO, Rep. WCDMP-47,WMO-TD 1071

Pigeon, G., Legain, D., Durand, P., Masson, V., 2007. Anthropogenic heat release in an old European agglomeration (Toulouse, France). Int. J. Climatol. 27, 1969-1981. https://doi.org/10.1002/joc. 1530

Qiu, G. yu, Li, H. yong, Zhang, Q. tao, Chen, W., Liang, X. jian, Li, X. ze, 2013. Effects of Evapotranspiration on Mitigation of Urban Temperature by Vegetation and Urban Agriculture. J. Integr. Agric. https://doi.org/10.1016/S2095-3119(13)60543-2

Quénol, H., Dubreuil, V., Mimet, A., Pellissier, V., Aguejdad, R., Clergeau, P., Bridier, S., 2010. Climat urbain et impact sur la phénologie végétale printanière 50-57.

Rafiee, A., Dias, E., Koomen, E., 2016. Local impact of tree volume on nocturnal urban heat island: A case study in Amsterdam. Urban For. Urban Green. 16, 50-61. https $/ /$ doi.org/10.1016/j.ufug.2016.01.008

Raynor, G.S., 1971. Wind and temperature structure in a coniferous forest and a contiguous field. For. Sci. $17,351-363$.

Rousseau, D., 2005. Analyse fine des surmortalités pendant la canicule 2003 : L'évènement météorologique de la nuit du 11 au 12 août 2003 en Île-de-France. La Météorologie 8, 16-22.

Schmid, H.P., Cleugh, H., Grimmond, C.S.B., Oke, T.R., 1991. Spatial variability of energy fluxes in suburban terrain 249-276.

Stéphan, F., Ghiglione, S., Decailliot, F., Yakhou, L., Duvaldestin, P., Legrand, P., 2005. Effect of excessive environmental heat on core temperature in critically ill patients. An observational study during the 2003 European heat wave. Br. J. Anaesth. 94, 39-45. https $/ /$ doi.org/10.1093/bja/aeh291

Stewart, I.D., Oke, T.R., 2012. Local Climate Zones for Urban Temperature Studies. Bull. Am. Meteorol. Soc. 93, 1879-1900. https://doi.org/10.1175/BAMS-D-11-00019.1

Stewart, I.D., Oke, T.R., 2010. Thermal differentiation of local climate zones using temperature observations from urban and rural field sites, in: Ninth Symposium on Urban Environment, Keystone, CO. pp. 2-6.

Stoutjesdijk, P.H., Barkman, J.J., 2014. Microclimate, vegetation \& fauna. Brill.

Suomi, J., Hjort, J., Käyhkö, J., 2012. Effects of scale on modelling the urban heat island in Turku, SW Finland. Clim. Res. 55, 105-118. https://doi.org/10.3354/cr01123

Suomi, J., Käyhkö, J., 2012. The impact of environmental factors on urban temperature variability in the coastal city of Turku, SW Finland. Int. J. Climatol. 32, 451-463.

https $/ /$ doi.org/10.1002/joc.2277 
Szymanowski, M., Kryza, M., 2011a. Application of geographically weighted regression for modelling the spatial structure of urban heat island in the city of Wroclaw (SW Poland). Procedia Environ. Sci. 3, 87-92. https://doi.org/10.1016/j.proenv.2011.02.016

Szymanowski, M., Kryza, M., 2011b. Local regression models for spatial interpolation of urban heat island - an example from Wrocław, SW Poland. Theor. Appl. Climatol. 108, 53-71. https $/ /$ doi.org/10.1007/s00704-011-0517-6

Szymanowski, M., Kryza, M., 2009. GIS-based techniques for urban heat island spatialization. Clim. Res. 38, 171-187. https://doi.org/10.3354/cr00780

Tremeac, B., Bousquet, P., de Munck, C., Pigeon, G., Masson, V., Marchadier, C., Merchat, M., Poeuf, P., Meunier, F., 2012. Influence of air conditioning management on heat island in Paris air street temperatures. Appl. Energy 95, 102-110. https://oi.org/10.1016/j.apenergy.2012.02.015

United Nations, 2013. World Population Prospects: The 2012 Revision [WWW Document]. World Popul. Prospect. 2012 Revis. https://doi.org/21 February 2014

Van der Poel, A.J., Stoutjesdijk, P., 1959. Some microclimatological differences between an oak wood and a Calluna heath. Med. Landbouwhogesch. Wageningen 59, 1-8.

Voogt, J. a., Oke, T.R., 2003. Thermal remote sensing of urban climates. Remote Sens. Environ. 86, 370-384. https://doi.org/10.1016/S0034-4257(03)00079-8

Voogt, J.A., Munn, T., 2002. Urban Heat Island Urban Heat Island. Int. J. Remote Sens., Reducing Urban Heat Islands: Compendium of Strategies 3, 660-666.

Yoshino, M., 1975. Climate in a Small Area: An Introduction to Local Meteorology.

Zhang, X., Hegerl, G., Zwiers, F.W., Kenyon, J., 2005. Avoiding inhomogeneity in percentile-based indices of temperature extremes. J. Clim. 18, 1641-1651. https://doi.org/10.1175/JCLI3366.1

Zhao, C., Fu, G., Liu, X., Fu, F., 2011. Urban planning indicators, morphology and climate indicators: A case study for a north-south transect of Beijing, China. Build. Environ. 46, 1174-1183. https $/ /$ doi.org/10.1016/j.buildenv.2010.12.009 


\section{Highlights}

- 22 weather stations recorded the UHI intensity in a mid-size city.

- The occurrence of the UHI is about $25 \%$.

- A statistical model mapped the UHI for several periods (annual, seasonal and daily).

- The buffers radii of low vegetation fraction (900m) and built-up fraction (200m) explained mainly the UHI. 